\title{
Characterisation of Shiga toxin-producing Escherichia coli O I 57 strains isolated from humans in Argentina, Australia and New Zealand
}

\author{
Gerardo A Leotta1,2, Elizabeth S Miliwebsky1, Isabel Chinen1, \\ Estela M Espinosa ${ }^{1}$, Kristy Azzopardi ${ }^{3}$, Sharon M Tennant ${ }^{3}$, Roy M Robins- \\ Browne*3 $^{* 3}$ and Marta Rivas ${ }^{1}$
}

\begin{abstract}
Address: ${ }^{1 S e r v i c i o ~ F i s i o p a t o g e n i a, ~ I n s t i t u t o ~ N a c i o n a l ~ d e ~ E n f e r m e d a d e s ~ I n f e c c i o s a s ~-~ A N L I S ~ " D r . ~ C a r l o s ~ G . ~ M a l b r a ́ n " . ~ A v . ~ V e ́ l e z ~ S a r s f i e l d ~} 563$ (1281) Ciudad Autónoma de Buenos Aires, Argentina, ${ }^{2}$ Consejo Nacional de Investigaciones Científicas y Técnicas (CONICET), Argentina and ${ }^{3}$ Department of Microbiology and Immunology, University of Melbourne, and Murdoch Childrens Research Institute, Royal Children's Hospital, Parkville Victoria 3010, Australia

Email: Gerardo A Leotta - galeotta@anlis.gov.ar; Elizabeth S Miliwebsky - emiliwebsky@anlis.gov.ar; Isabel Chinen - ichinen@anlis.gov.ar; Estela M Espinosa - elmartinez@anlis.gov.ar; Kristy Azzopardi - kristy.azzopardi@mcri.edu.au; Sharon M Tennant - stennant@medicine.umaryland.edu; Roy M Robins-Browne* - r.browne@unimelb.edu.au; Marta Rivas - mrivas@anlis.gov.ar

* Corresponding author
\end{abstract}

Published: 17 March 2008

BMC Microbiology 2008, 8:46 doi:10.1 I86/I47I-2180-8-46

This article is available from: http://www.biomedcentral.com/I47|-2/80/8/46

(c) 2008 Leotta et al; licensee BioMed Central Ltd.

This is an Open Access article distributed under the terms of the Creative Commons Attribution License (http://creativecommons.org/licenses/by/2.0), which permits unrestricted use, distribution, and reproduction in any medium, provided the original work is properly cited.

\begin{abstract}
Background: Shiga toxin-producing Escherichia coli (STEC) is an important cause of bloody diarrhoea (BD), non-bloody diarrhoea (NBD) and the haemolytic uraemic syndrome (HUS). In Argentina and New Zealand, the most prevalent STEC serotype is OI57:H7, which is responsible for the majority of HUS cases. In Australia, on the other hand, STEC OI57:H7 is associated with a minority of HUS cases. The main aims of this study were to compare the phenotypic and genotypic characteristics of STEC OI57 strains isolated between 1993 and 1996 from humans in Argentina, Australia and New Zealand, and to establish their clonal relatedness.

Results: Seventy-three OI57 STEC strains, isolated from HUS $(n=36)$, BD $(n=20)$, NBD $(n=10)$, or unspecified conditions ( $n=7)$ in Argentina, Australia and New Zealand, were analysed. The strains were confirmed to be E. coli OI57 by biochemical tests and serotyping. A multiplex polymerase chain reaction (PCR) was used to amplify the $s t x_{1}$, stx $x_{2}$ and $r f b_{\mathrm{O} \mid 57}$ genes and a genotyping method based on PCR-RFLP was used to determine $s t x_{1}$ and $s t x_{2}$ variants. This analysis revealed that the most frequent stx genotypes were $s t x_{2} / s t x_{2 c \text { (vh-a) }}(91 \%)$ in Argentina, $s t x_{2}(89 \%)$ in New Zealand, and $s t x_{1} / s t x_{2}(30 \%)$ in Australia. No stx 1 -postive strains were identified in Argentina or New Zealand. All strains harboured the eae gene and 72 strains produced enterohaemolysin (EHEC-Hly). The clonal relatedness of strains was investigated by phage typing and pulsed-field gel electrophoresis (PFGE). The most frequent phage types (PT) identified in Argentinian, Australian, and New Zealand strains were PT49 $(n=12)$, PTI4 $(n=9)$, and PT2 $(n=15)$, respectively. Forty-six different patterns were obtained by Xbal-PFGE; 37 strains were grouped in 10 clusters and 36 strains showed unique patterns. Most clusters could be further subdivided by BInI-PFGE.

Conclusion: STEC OI57 strains isolated in Argentina, Australia, and New Zealand differed from each other in terms of stx-genotype and phage type. Additionally, no common PFGE patterns were found in strains isolated in the three countries. International collaborative studies of the type reported here are needed to detect and monitor potentially hypervirulent STEC clones.
\end{abstract}




\section{Background}

Shiga toxin-producing Escherichia coli (STEC) is an important emerging pathogen which can cause bloody diarrhoea (BD), non-bloody diarrhoea (NBD) and the haemolytic uraemic syndrome (HUS). The ability of STEC strains to cause severe disease in humans is related to their capacity to secrete Shiga toxins, Stx1 and Stx2, and variants of these toxins $[1,2]$. Another virulence-associated factor of most STEC isolates associated with severe disease is intimin, a $94-\mathrm{kDa}$ outer membrane protein, which is encoded by the eae gene on a ca. 34-kb chromosomal pathogenicity island termed the locus of enterocyte effacement (LEE). This locus is associated with the intimate adherence of $E$. coli to epithelial cells, initiation of host signal transduction pathways, and the formation of attaching-and-effacing intestinal lesions [3]. In addition, most STEC strains associated with BD or HUS produce an enterohaemolysin (EHEC-Hly), encoded by a plasmidborne gene, known as ehxA [4].

Argentina has a high incidence of HUS: 13.9 cases per 100,000 children younger than 5 years old were reported in 2005 [5]. This rate is 10-fold higher than in other industrialised countries [6]. In Argentina STEC is the primary aetiological agent of HUS, and E. coli O157:H7 is the predominant serotype isolated [7]. In Australia and New Zealand the annual incidence of HUS, determined through active surveillance, is approximately 1.0 to 1.3 per 100,000 children less than 5 years old [8]. Interestingly, the predominant STEC serotypes associated with HUS in these two countries differs. Whereas in New Zealand $\mathrm{O} 157$ strains make up around half of the isolates, in Australia serotype O111 STEC account for most HUS cases, with O157 associated with fewer than 20\% [8,9]. The reasons for these differences are not known.

The aims of this study were to compare the phenotypic and genotypic characteristics of STEC O157 strains isolated from humans in Argentina, Australia and New Zealand during the period 1993-1996, and to establish the genetic diversity and clonal relatedness among the strains isolated in these three countries. The rationale for under- taking this study was based upon national and international concerns that modern centralised and rapid food distribution systems in these countries together with recent increases in the volume of food trade internationally and the enormous increase in global travel could allow the unfettered, and undetected, worldwide spread of virulent clones of STEC O157.

\section{Results}

Of the 73 strains examined ( 35 from Argentina, 20 from Australia and 18 from New Zealand), 36 were isolated from HUS cases, 20 from BD cases, and 10 from NBD cases. The clinical origin of 7 strains was not specified (Table 1). All strains were confirmed as E. coli O157, were cytotoxic for Vero cells, and carried the genes encoding intimin and $f l i \mathrm{C}_{\mathrm{H} 7}$, even though several were non-motile in vitro, and were typed as O157:H- (data not shown). Production of enterohaemolysin was observed in 72 $(98.6 \%)$ of 73 strains, in agreement with the polymerase chain reaction (PCR) results.

PCR-restriction fragment length polymorphism (RFLP) genotyping of the 73 O157 STEC strains showed that 35 $(48 \%)$ strains harboured $s t x_{2}$ and $s t x_{2 c}(\mathrm{vh}-\mathrm{a}), 22(30 \%)$ carried only $s t x_{2}, 6(8 \%)$ carried $s t x_{1}$ and $s t x_{2}, 4(5 \%)$ carried $s t x_{1}$ and $s t x_{2 c}(\mathrm{vh}-\mathrm{a})^{\prime}, 3(4 \%)$ carried only $s t x_{2 \mathrm{c}}(\mathrm{vh}-\mathrm{a}), 2$ (3\%) carried only stx $x_{1}$ and $1(1 \%)$ carried $s t x_{1}$ and stx $x_{2 \text {-UT }}$ (Table 2 ). The most frequent stx genotypes were $s t x_{2}$ and $s t x_{2 c}$ (vha) $(32 / 35 ; 91 \%)$ in Argentina, $\operatorname{stx}_{1}$ and $s t x_{2}(6 / 20 ; 30 \%)$ in Australia, and $s t x_{2}(16 / 18 ; 89 \%)$ in New Zealand. $s t x_{2}$ was the only stx-genotype found in all 3 countries. No $s t x_{1}$ positive strains were obtained from patients in Argentina or New Zealand, compared with 13 of 20 from Australia $(P<0.0001$; Fisher's exact test, two-tailed $)$. Of the $13 s t x_{1}$ positive strains isolated in Australia, however, 11 were also positive for $\mathrm{stx}_{2}$ or $s t x_{2 \mathrm{c}}$. Notwithstanding these difference in toxin profile, there was no significant association between stx genotype and the clinical presentation of the patient from whom the strain was obtained (Table 3; $P$ > 0.5, Kruskal-Wallis test).

Table I: Clinical presentation of patients in Argentina, Australia, and New Zealand from whom STEC OI57 strains were isolated between 1993 and 1996.

No. (\%) of strains from:

\begin{tabular}{|c|c|c|c|}
\hline \multirow[b]{2}{*}{ Clinical presentation } & \multirow[b]{2}{*}{ Argentina } & \\
\hline & & Australia & New Zealand \\
\hline Haemolytic uraemic syndrome & $22(63)$ & $6(30)$ & $8(44)$ \\
\hline Bloody diarrhoea & $10(29)$ & $3(15)$ & 7 (39) \\
\hline Non-bloody diarrhoea & $3(9)$ & $5(25)$ & $2(22)$ \\
\hline Non-specific & $0(0)$ & $6(30)$ & I (6) \\
\hline & $35(100)$ & $20(100)$ & $18(100)$ \\
\hline
\end{tabular}


Table 2: stx genotype of STEC OI57 strains isolated between 1993 and 1996 from humans in Argentina, Australia and New Zealand.

\begin{tabular}{|c|c|c|c|}
\hline \multirow[b]{2}{*}{ stx genotype } & \multicolumn{3}{|c|}{ No. (\%) of strains from: } \\
\hline & Argentina & Australia & New Zealand \\
\hline$s t x_{1}$ & 0 & $2(10)$ & 0 \\
\hline$s t x_{2}$ & $3(9)$ & $3(15)$ & $16(89)$ \\
\hline$s t x_{2 c(v h-a)}$ & 0 & I (5) & $2(11)$ \\
\hline$s t x_{1} / s t x_{2}$ & 0 & $6(30)$ & 0 \\
\hline$s t x_{1} / s t x_{2 c}($ vh-a) & 0 & $4(20)$ & 0 \\
\hline$s t x_{1} / s t x_{2-U T}$ & 0 & I (5) & 0 \\
\hline$s t x_{2} / s t x_{2 c}$ (vh-a) & $32(91)$ & $3(15)$ & 0 \\
\hline Total & $35(100)$ & $20(100)$ & $18(100)$ \\
\hline
\end{tabular}

The most frequent phage types (PT) identified in Argentina, Australia, and New Zealand were PT49 (12/35; 34\%), PT14 (9/20; 45\%), and PT2 (15/18; 83\%), respectively (Table 4). PT4 was the only PT found in all 3 countries with frequencies of 31\% (11/35) in Argentina; 15\% $(3 / 20)$ in Australia, and $11 \%(2 / 18)$ in New Zealand. There was no significant association between phage type and the clinical presentation of the patient from whom the strain was obtained $(P>0.5$, Kruskal-Wallis test $)$.

Pulsed-field gel electrophoresis (PFGE) of XbaI-digested genomic DNA was used to subtype all 73 STEC O157 strains, generating 46 distinct PFGE patterns with 16-24 discernible fragments, ranging from approximately 32 to $730 \mathrm{~kb}$ in size. Twenty-one patterns were identified amongst 35 strains isolated in Argentina, 14 patterns in 20 strains from Australia, and 11 patterns in 18 strains from New Zealand.

Table 3: Distribution of STEC OI57 strains isolated from humans with haemolytic uraemic syndrome (HUS), bloody diarrhoea (BD), non-bloody diarrhoea (NBD) or other nonspecified conditions (NS) according to stx genotype.

\begin{tabular}{|c|c|c|c|c|}
\hline \multirow[b]{2}{*}{ stx genotype } & \multicolumn{4}{|c|}{ No. (\%) of strains from patients with : } \\
\hline & HUS & BD & NBD & NS \\
\hline$s t x_{1}$ & 0 & 0 & $2(20)$ & 0 \\
\hline$s t x_{2}$ & $12(33)$ & $6(30)$ & $3(30)$ & I (I4) \\
\hline$s t x_{2 c}(\mathrm{vh}-\mathrm{a})$ & 0 & $2(10)$ & $I(10)$ & 0 \\
\hline$s t x_{1} / s t x_{2}$ & I (3) & 0 & 0 & $5(7 I)$ \\
\hline$s t x_{1} / s t x_{2 c}(v h-a)$ & I (3) & $2(10)$ & $\mathrm{I}(10)$ & 0 \\
\hline$s t x_{1} / s t x_{2-U T}$ & 0 & 0 & 0 & I (I4) \\
\hline$s t x_{2} / s t x_{2 c}$ (vh-a) & $22(61)$ & $10(50)$ & $3(30)$ & 0 \\
\hline Total & $36(100)$ & $20(100)$ & $10(100)$ & $7(100)$ \\
\hline
\end{tabular}

Table 4: Phage type of STEC OI 57 strains isolated between 1993 and 1996 from humans in Argentina, Australia and New Zealand.

\begin{tabular}{|c|c|c|c|}
\hline \multirow[b]{2}{*}{ Phage type } & \multicolumn{3}{|c|}{ No. (\%) of strains from: } \\
\hline & Argentina & Australia & New Zealand \\
\hline I & 0 & I (5) & 0 \\
\hline 2 & $8(23)$ & 0 & $15(83)$ \\
\hline 4 & $11(3 I)$ & $3(15)$ & $2(11)$ \\
\hline 14 & I (3) & $9(45)$ & 0 \\
\hline 21 & 0 & I (5) & 0 \\
\hline 26 & $2(6)$ & I (5) & 0 \\
\hline 32 & 0 & 0 & I (6) \\
\hline 49 & $12(34)$ & 0 & 0 \\
\hline 54 & 0 & $3(15)$ & 0 \\
\hline Untypeable & I (3) & $2(10)$ & 0 \\
\hline Total & $35(100)$ & $20(100)$ & $18(100)$ \\
\hline
\end{tabular}

Ten clusters contained isolates with indistinguishable XbaI-PFGE profiles (Figure 1). These were cluster I (3 strains from Argentina); cluster II (3 strains from Australia); cluster III (2 strains from Argentina); cluster IV (5 strains from Argentina); cluster V (2 strains from New Zealand); cluster VI (8 strains from Argentina); cluster VII (2 strains from New Zealand); cluster VIII (4 strains from New Zealand); cluster IX (3 strains from New Zealand); and cluster X ( 5 strains from Australia). To refine the cluster analysis further, we determined the BhI-PFGE profile of each isolate. This revealed that most strains with identical XbaI-PFGE pattern could be discerned from each other by restriction with a second enzyme (Table 5). Some clusters could also be split by using phage typing and $s t x$ genotyping (Table 5). Only two clusters, II (3 strains) and $\mathrm{X}$ (5 strains), both from Australia, were indistinguishable by XbaI- and BlnI-PFGE, phage typing and stx-genotyping, indicating that these were probable clones.

In Argentina, the predominant XbaI-PFGE patterns were AREXHX01-0011 (cluster VI, 8 strains), AREXHX01-0022 (cluster IV, 5 strains), AREXHX01-0013 (cluster I, 3 strains) and AREXHX01-0014 (cluster III, strains). The eight strains in cluster VI were recovered from three HUS cases and one BD case in 1993. and from two HUS cases and two BD cases in 1996. All of these isolates carried $s t x_{2}$ and $s t x_{2 c}$ (vh-a), except one strain isolated from a patient with HUS which carried $s t x_{2}$ only. Seven strains belonged to PT4, and one to PT26. Four of the five strains in cluster IV carried $s t x_{2}$ and $s t x_{2 c}(\mathrm{vh}-\mathrm{a})$. Four strains in this cluster were isolated from one case each of NBD, BD, and two of HUS in 1996. Three of these strains belonged to PT49, and one to PT4. The three $s t x_{2} / s t x_{2 c}$ (vh-a) PT49 strains in this cluster showed the same pattern on BlnI-PFGE and are likely to be a clone. The remaining strain in this cluster carried $s t x_{2}$, belonged to PT49, and was recovered from an 


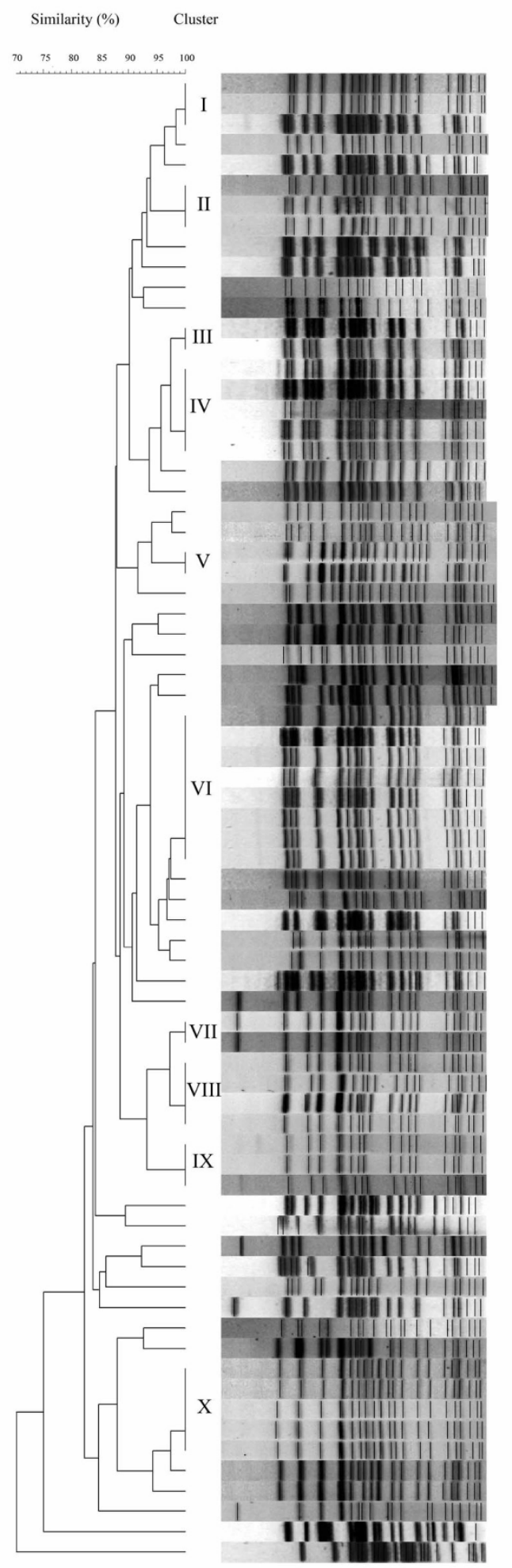

\begin{tabular}{|c|c|c|c|c|c|}
\hline Origin & $\begin{array}{l}\text { Isolation } \\
\text { year }\end{array}$ & $\begin{array}{c}\text { Clinical } \\
\text { Presentation }\end{array}$ & $\begin{array}{c}\text { XbaI-PFGE } \\
\text { Pattern No. }\end{array}$ & $\begin{array}{c}\text { Phage } \\
\text { type }\end{array}$ & $\begin{array}{c}\text { stx } \\
\text { genotype }\end{array}$ \\
\hline Argentina & 1993 & BD & AREXHX01-0013 & 14 & $s t x_{2} / s t x_{2 \mathrm{vh}-\mathrm{a}}$ \\
\hline Argentina & 1996 & BD & AREXHX01-0013 & 49 & $s t x_{2} / s t x_{2} \mathrm{vb}-\mathrm{a}$ \\
\hline Argentina & 1996 & HUS & AREXHX01-0013 & UT & $s t x_{2} / s t x_{2} \mathrm{vh}-\mathrm{a}$ \\
\hline Australia & 1993 & NBD & AUEXHX01-0001 & 26 & $s t x_{1}$ \\
\hline Argentina & 1996 & HUS & AREXHX01-0032 & 49 & $s t x_{2} / s t x_{2} \mathrm{vh}-\mathrm{a}$ \\
\hline Australia & 1996 & HUS & AUEXHX01-0014 & 54 & $s t x_{2} /$ st $x_{2 \mathrm{vh}-\mathrm{a}}$ \\
\hline Australia & 1996 & HUS & AUEXHX01-0014 & 54 & st $x_{2} /$ st $x_{2 \mathrm{vh}-\mathrm{a}}$ \\
\hline Australia & 1996 & HUS & AUEXHX01-0014 & 54 & $s t x_{2} / s t x_{2 \mathrm{vh}-\mathrm{a}}$ \\
\hline Argentina & 1996 & HUS & AREXHX01-0031 & 49 & st $x_{2} /$ st $x_{2 \mathrm{vb}-\mathrm{a}}$ \\
\hline Argentina & 1994 & HUS & AREXHX01-0018 & 2 & $s t x_{2} / s t x_{2 \mathrm{v} h \mathrm{a}}$ \\
\hline Argentina & 1996 & NBD & AREXHX01-0037 & 2 & st $x_{2} /$ st $x_{2}$ vh-a \\
\hline Argentina & 1996 & BD & AREXHX01-0027 & 2 & $s t x_{2} / s t x_{2 \mathrm{vh}-\mathrm{a}}$ \\
\hline Argentina & 1995 & HUS & AREXHX01-0014 & 49 & $s t x_{2} /$ st $x_{2}$ wh-a \\
\hline Argentina & 1993 & $\mathrm{BD}$ & AREXHX01-0014 & 49 & $s t x_{2} / s t x_{2 \mathrm{vh}-\mathrm{a}}$ \\
\hline Argentina & 1995 & HUS & AREXHX01-0022 & 49 & st $x_{2}$ \\
\hline Argentina & 1996 & HUS & AREXHX01-0022 & 49 & $s t x_{2} / s t x_{2 \mathrm{vh}-\mathrm{a}}$ \\
\hline Argentina & 1996 & NBD & AREXHX01-0022 & 4 & $s t x_{2} / s t x_{2} \mathrm{vh}-\mathrm{a}$ \\
\hline Argentina & 1996 & HUS & AREXHX01-0022 & 49 & $s t x_{2} / s t x_{2} \mathrm{vh}-\mathrm{a}$ \\
\hline Argentina & 1996 & $\mathrm{BD}$ & AREXHX01-0022 & 49 & $s t x_{2} / s t x_{2} \mathrm{vh-a}$ \\
\hline Argentina & 1996 & HUS & AREXHX01-0030 & 2 & $s t x_{2} / s x_{2 \mathrm{vh}-\mathrm{a}}$ \\
\hline Argentina & 1996 & BD & AREXHX01-0033 & 49 & $s t x_{2} / s t x_{2 \mathrm{vh}-\mathrm{a}}$ \\
\hline New Zealand & 1993 & HUS & NZEXHX01-0002 & 2 & $s t x_{2}$ \\
\hline New Zealand & 1993 & HUS & NZEXHX01-0004 & 2 & $s t x_{2}$ \\
\hline New Zealand & 1996 & $\mathrm{BD}$ & NZEXHX01-0010 & 2 & $s t x_{2}$ \\
\hline New Zealand & 1996 & $\mathrm{BD}$ & NZEXHX01-0010 & 2 & $s t x_{2}$ \\
\hline New Zealand & 1993 & HUS & NZEXHX01-0001 & 2 & $s t x_{2}$ \\
\hline Australia & 1996 & NBD & AUEXHX01-0010 & 4 & $s t x_{1} / s t x_{2 \mathrm{vh}-\mathrm{a}}$ \\
\hline New Zealand & 1995 & NBD & NZEXHX01-0009 & 4 & $s t x_{2 \mathrm{vth}-\mathrm{a}}$ \\
\hline Australia & 1994 & NBD & AUEXHX01-0002 & 4 & $s t x_{1}$ \\
\hline Australia & 1996 & NBD & AUEXHX01-0009 & 14 & $s t x_{2}$ \\
\hline Australia & 1995 & BD & AUEXHX01-0007 & 4 & $s t x_{1} / s t x_{2 \mathrm{vh}-\mathrm{a}}$ \\
\hline Argentina & 1993 & HUS & AREXHX01-0011 & 4 & $s t x_{2} /$ st $x_{2}$ vh-a \\
\hline Argentina & 1993 & HUS & AREXHX01-0011 & 26 & $s t x_{2} / s t x_{2 \mathrm{vh}-\mathrm{a}}$ \\
\hline Argentina & 1996 & $\mathrm{BD}$ & AREXHX01-0011 & 4 & $s t x_{2} / s t x_{2 \mathrm{v} h-\mathrm{a}}$ \\
\hline Argentina & 1993 & $\mathrm{BD}$ & AREXHX01-0011 & 4 & $s t x_{2} / s t x_{2 \mathrm{vh}-\mathrm{a}}$ \\
\hline Argentina & 1996 & HUS & AREXHX01-0011 & 4 & $s t x_{2} / s t x_{2 v \mathrm{~h}-\mathrm{a}}$ \\
\hline Argentina & 1993 & HUS & AREXHX01-0011 & 4 & $s t x_{2} /$ stx $x_{2 \mathrm{vh}-\mathrm{a}}$ \\
\hline Argentina & 1996 & BD & AREXHX01-0011 & 4 & $s t x_{2} / s t x_{2} \mathrm{vh}-\mathrm{a}$ \\
\hline Argentina & 1996 & HUS & AREXHX01-0011 & 4 & $s t x_{2}$ \\
\hline Argentina & 1996 & HUS & AREXHX01-0023 & 4 & st $x_{2} /$ st $x_{2 \mathrm{vh}-\mathrm{a}}$ \\
\hline New Zealand & 1995 & $\mathrm{BD}$ & NZEXHX01-0007 & 4 & $s t x_{2 \mathrm{vih}-\mathrm{a}}$ \\
\hline Argentina & 1996 & HUS & AREXHX01-0024 & 4 & $s t x_{2} /$ stx $x_{2 \mathrm{vh}-\mathrm{a}}$ \\
\hline Australia & 1994 & $\mathrm{BD}$ & AUEXHX01-0003 & 14 & $s t x_{2 \mathrm{vh}-\mathrm{a}}$ \\
\hline Australia & 1995 & NBD & AUEXHX01-0004 & UT & $s t x_{2}$ \\
\hline Argentina & 1993 & HUS & AREXHX01-0016 & 2 & $s t x_{2} / s t x_{2 \mathrm{vh}-\mathrm{a}}$ \\
\hline New Zealand & 1995 & HUS & NZEXHX01-0008 & 2 & $s t x_{2}$ \\
\hline New Zealand & 1996 & NBD & NZEXHX01-0006 & 2 & st $x_{2}$ \\
\hline New Zealand & 1995 & HUS & NZEXHX01-0006 & 2 & $s t x_{2}$ \\
\hline New Zealand & 1994 & $\mathrm{BD}$ & NZEXHX01-0005 & 2 & $s t x_{2}$ \\
\hline New Zealand & 1995 & BD & NZEXHX01-0005 & 2 & $s t x_{2}$ \\
\hline New Zealand & 1996 & BD & NZEXHX01-0005 & 2 & $s t x_{2}$ \\
\hline New Zealand & 1994 & HUS & NZEXHX01-0005 & 2 & stx $x_{2}$ \\
\hline New Zealand & 1994 & BD & NZEXHX01-0003 & 2 & $s t x_{2}$ \\
\hline New Zealand & 1993 & HUS & NZEXHX01-0003 & 2 & $s t x_{2}$ \\
\hline New Zealand & 1993 & HUS & NZEXHX01-0003 & 2 & st $x_{2}$ \\
\hline Argentina & 1996 & HUS & AREXHX01-0034 & 2 & $s t x_{2} /$ st $x_{2}$ wh-a \\
\hline Argentina & 1996 & HUS & AREXHX01-0025 & 26 & $s t x_{2} / s t x_{2}$ vh-a \\
\hline Australia & 1995 & HUS & AUEXHX01-0008 & UT & $s t x_{1} / s t x_{2 \mathrm{vh}-\mathrm{a}}$ \\
\hline Argentina & 1996 & HUS & AREXHX01-0020 & 4 & $s t x_{2} / s t x_{2}$ vh-a \\
\hline Australia & 1995 & $\mathrm{BD}$ & AUEXHX01-0006 & 1 & $s t x_{1} / s t x_{2} \mathrm{vh}-\mathrm{a}$ \\
\hline Argentina & 1994 & HUS & AREXHX01-0017 & 49 & $s t x_{2} / s t x_{2 \text { vh-a }}$ \\
\hline Argentina & 1996 & $\mathrm{BD}$ & AREXHX01-0026 & 2 & $s t x_{2} / s t x_{2} \mathrm{vh}-\mathrm{a}$ \\
\hline New Zealand & 1996 & NS & NZEXHX01-0011 & 32 & $s t x_{2}$ \\
\hline Australia & 1996 & NS & AUEXHX01-0013 & 14 & $s t x_{1} / s t x_{2}$ \\
\hline Australia & 1996 & NS & AUEXHX01-0013 & 14 & $s t x_{1} / s t x_{2}$ \\
\hline Australia & 1996 & NS & AUEXHX01-0013 & 14 & $s t x_{1} / s t x_{2}$ \\
\hline Australia & 1996 & NS & AUEXHX01-0013 & 14 & $s t x_{1} / s t x_{2}$ \\
\hline Australia & 1996 & HUS & AUEXHX01-0013 & 14 & $s t x_{1} / s t x_{2}$ \\
\hline Australia & 1996 & NS & AUEXHX01-0011 & 14 & $s t x_{1} / s t x_{2}$-UT \\
\hline Australia & 1996 & NS & AUEXHX01-0012 & 14 & $s t x_{1} / s t x_{2}$ \\
\hline Australia & 1995 & HUS & AUEXHX01-0005 & 21 & $s t x_{2}$ \\
\hline Argentina & 1996 & NBD & AREXHX01-0028 & 2 & $s t x_{2} / s t x_{2 \mathrm{vh}-\mathrm{a}}$ \\
\hline Argentina & 1996 & HUS & AREXHX01-0021 & 49 & $s t x_{2}$ \\
\hline
\end{tabular}

Figure I

Clonal relationship of 73 STEC OI57 strains isolated between 1993 and 1996 from humans in Argentina, Australia, and New Zealand. 
Table 5: Discrimination of STEC OI57 strains within Xbal-PFGE clusters by phage type, stx genotype and BInI-PFGE.

\begin{tabular}{|c|c|c|c|c|}
\hline Cluster/No. of Xbal-PFGE & No. of strains & Phage type & stx genotype & Blnl-PFGE pattern \\
\hline \multirow[t]{3}{*}{ I (AREXHXOI-00I3) } & 1 & 14 & $s t x_{2}$ and $s t x_{2 c}($ vh-a) & AREXHA26-00I3 \\
\hline & 1 & 49 & $s t x_{2}$ and $s t x_{2 c}($ (vh-a) & AREXHA26-00I5 \\
\hline & I & UT & $s t x_{2}$ and $s t x_{2 c}($ (vh-a) & AREXHA26-0024 \\
\hline II (AUEXHXOI-00I4) & 3 & 54 & $s t x_{2}$ and $s t x_{2 c}($ (vh-a) & AUEXHA26-0002 \\
\hline \multirow[t]{2}{*}{ III (AREXHXOI-00I4) } & 1 & 49 & $s t x_{2}$ and $s t x_{2 c}($ (vh-a) & AREXHA26-00I8 \\
\hline & 1 & 49 & $s t x_{2}$ and $s t x_{2 c}($ (vh-a) & AREXHA26-00I5 \\
\hline \multirow[t]{3}{*}{ IV (AREXHXOI-0022) } & 3 & 49 & $s t x_{2}$ and $s t x_{2 c}(\mathrm{vh}-\mathrm{a})$ & AREXHA26-00I5 \\
\hline & 1 & 4 & $s t x_{2}$ and $s t x_{2 c}($ vh-a) & AREXHA26-00I5 \\
\hline & i & 49 & $s t x_{2}$ & AREXHA26-0019 \\
\hline \multirow[t]{2}{*}{ V (NZEXHXOI-00I0) } & 1 & 2 & $s t x_{2}$ & NZEXHA26-0003 \\
\hline & I & 2 & $s t x_{2}$ & NZEXHA26-0007 \\
\hline \multirow[t]{7}{*}{ VI (AREXHXOI-00II) } & 2 & 4 & $s t x_{2}$ and $s t x_{2 c}($ vh-a) & AREXHA26-0008 \\
\hline & I & 4 & $s t x_{2}$ and $s t x_{2 c}($ (vh-a) & AREXHA26-003I \\
\hline & I & 26 & $s t x_{2}$ and $s t x_{2 c}(\mathrm{vh}-\mathrm{a})$ & AREXHA26-00II \\
\hline & I & 4 & $s t x_{2}$ and $s t x_{2 c}(\mathrm{vh}-\mathrm{a})$ & AREXHA26-0023 \\
\hline & 1 & 4 & $s t x_{2}$ and $s t x_{2 c}(\mathrm{vh}-\mathrm{a})$ & AREXHA26-0022 \\
\hline & 1 & 4 & $s t x_{2}$ and $s t x_{2 c}($ vh-a) & AREXHA26-0009 \\
\hline & 1 & 4 & $s t x_{2}$ & AREXHA26-0025 \\
\hline \multirow[t]{2}{*}{ VII (NZEXHXOI-0006) } & 1 & 2 & $s t x_{2}$ & NZEXHA26-0005 \\
\hline & I & 2 & $s t x_{2}$ & NZEXHA26-0004 \\
\hline \multirow[t]{3}{*}{ VIII (NZEXHXOI-0005) } & 2 & 2 & $s t x_{2}$ & NZEXHA26-000I \\
\hline & I & 2 & $s t x_{2}$ & NZEXHA26-0002 \\
\hline & I & 2 & $s t x_{2}$ & NZEXHA26-0006 \\
\hline \multirow[t]{3}{*}{ IX (NZEXHXOI-0003) } & I & 2 & $s t x_{2}$ & NZEXHA26-000I \\
\hline & I & 2 & $s t x_{2}$ & NZEXHA26-0002 \\
\hline & I & 2 & $s t x_{2}$ & NZEXHA26-0003 \\
\hline X (AUEXHXOI-00I3) & 5 & 14 & $s t x_{1}$ and $s t x_{2}$ & AUEXHA26-000I \\
\hline
\end{tabular}

HUS case in 1995. The three strains in cluster I carried stx and $s t x_{2 c}$ (vh-a) and were isolated from a BD case in 1993, and from a BD and a HUS case in 1996. All three belonged to different PTs (PT49, PT14, and PT-UT). The two strains in cluster III, carried $s t x_{2}$ and $s t x_{2 c}$ (vh-a), belonged to PT49 and were isolated from a BD case in 1993, and an HUS case in 1995.

In Australia, the predominant XbaI-PFGE patterns were AUEXHX01-0013 (cluster X, 5 strains), and AUEXHX010014 (cluster II, 3 strains). All five strains in cluster X carried $s t x_{1}$ and $s t x_{2}$, belonged to PT14, and were isolated in 1996 from one HUS case, two contacts of this case and from two individuals with an unspecified disease other than HUS or diarrhoea. These strains also showed the same BlnI-PFGE pattern (Table 5). All three strains in cluster II carried $s t x_{2}$ and $s t x_{2 c}$ (vh-a), belonged to PT54 and were isolated from HUS cases in 1996. The strains were also indistinguishable by BlnI-PFGE. The only enterohaemolysin-negative strain in this study carried $s t x_{2}$ alone, belonged to PT21 and was isolated from a HUS case in 1995.

In New Zealand, the predominant XbaI-PFGE patterns were NZEXHX01-0005 (cluster VIII, 4 strains), NZEXHX01-0003 (cluster IX, 3 strains), NZEXHX01-0010 (cluster V, 2 strains), and NZEXHX01-0006 (cluster VII, 2 strains). The four strains in cluster VIII were isolated from BD cases in 1994, 1995 and 1996, and from a HUS case in 1994. The three strains in cluster IX were obtained from two HUS cases in 1993 and one case of BD in 1994. The two strains in cluster $\mathrm{V}$ were isolated from $\mathrm{BD}$ cases in 1996, and the two strains in cluster VII were isolated from an HUS case in 1995 and a NBD case in 1996. All 11 strains harboured $s t x_{2}$ and were the same phage type (PT2).

\section{Discussion}

This study revealed differences in the stx genotype, phage type and PFGE profiles of clinically-significant STEC O157 strains isolated from humans in Argentina, Australia and New Zealand. Strains that possessed both stx and $s t x_{2}$ were relatively more prevalent in Australia as is the case in the USA [10], Japan [11] and Chile [12], amongst others. On the other hand, the relatively high prevalence of $s t x_{2}$-positive strains in New Zealand resembles the toxin profile of STEC O157 in Western Europe $[13,14]$. In Argentina, all isolates were either $s t x_{2}$ or and $s t x_{2} / s x_{2 c}$ (vh-a), with $s t x_{2} / s t x_{2 c}$ (vh-a) strains accounting for more than $90 \%$ of isolates. This highly virulent genotype has been described by Nishikawa et al. [15] as being associated with severe human disease. The high frequency of 
this toxin profile in isolates from Argentina, and that of Stx2-producing STEC in New Zealand, which are also reportedly more virulent than other strains [16], compared with Australia (Table 2), may account in part for the relatively low frequency of severe infection with STEC O157 in Australia compared with the other countries. Our finding that $s t x$ profile was not significantly associated with clinical presentation, may have been due to a sampling error, in that isolates from the sickest patients are more likely to be sent to reference laboratories for characterisation.

At least 90 phage types have been reported for STEC O157 [17], but only four of these (PT2, PT4, PT14, and PT49) accounted for $84 \%$ of the strains analysed in this study. In Europe and Canada, PT2, PT4, PT8, PT14, PT21, PT32, and PT54 account for the majority (> 75\%) of STEC O157 strains obtained from humans [18]. Six of these PTs (PT2, PT4, PT14, PT21, PT32, and PT54), were identified in the present study, but only PT4 occurred in all three countries. PT2 and PT8 predominate among human strains of STEC O157 in Spain, Belgium, Finland, Germany, Italy, England and Scotland $[17,19]$. In our study, PT2 was predominant in New Zealand strains, and also was identified among the Argentinian strains, but not in Australian strains. PT8 was not identified in this study. PT14, predominant in Canada [17], was identified in Argentinian and Australian strains, but not in those from New Zealand. PT49 and PT4 were common in Argentina, but absent (PT49) or infrequent (PT4) in Australia and New Zealand.

PFGE is the "gold standard" of genetic fingerprinting methods for E. coli $\mathrm{O} 157$ and is particularly useful for tracking outbreak strains [20]. In this study a high degree of diversity was observed among the strains analysed by this technique. No common XbaI-PFGE pattern was found in strains isolated in Argentina, Australia or New Zealand. However, different clusters were detected in each country. The predominant XbaI-PFGE patterns were: AREXHX010011 (8 strains) in Argentina, AUEXHX01-0013 (5 strains) in Australia and NZEXHX01-0005 (4 strains) in New Zealand. The EXHX01-0011 and EXHX01-0022 patterns that were frequent in this study are common within the Argentinian Database, comprising 30\% of the STEC O157 isolates detected in different regions of Argentina during the last 10 years [5]. AREXHX01-0011 is indistinguishable from EXHX01-0047, the second most common pattern in the US national database, accounting for approximately $4.6 \%$ of strains. The most recent multistate outbreak with a strain of this pattern occurred in 2003 and was linked to beef, resulting in a food recall [21].
All but two of the XbaI-PFGE clusters could be subdivided by one or more of $s t x$ genotyping, phage typing and BlnIPFGE (Table 5). Those which could not be subdivided in this way included three strains that were epidemiologically related, and others that may have been responsible for small, undetected community outbreaks of infection. In the absence of pertinent data about the patients from whom these strains were obtained, however, we were unable to test this hypothesis.

\section{Conclusion}

The 73 STEC O157 strains isolated between 1993 and 1996 from symptomatic humans in Argentina, Australia and New Zealand differed in terms of stx-genotype and phage type. No common XbaI-PFGE pattern was found in the strains isolated in the three countries, indicating that there up until 1996 there was little spread of STEC O157 between them. Most isolates with common XbaI-PFGE patterns could be distinguished form each other by $s t x$ genotyping, phage typing or BlnI-PFGE. By conducting international collaborative studies, using standardised detection and typing tools of the type reported here, reference laboratories will be able to detect the emergence of potentially hypervirulent STEC clones and monitor their spread.

\section{Methods \\ Bacterial strains}

All 73 E. coli O157 strains of human origin submitted to the relevant microbiology reference laboratories in Argentina, Australia and New Zealand between 1993 and 1996 were studied. Each strain represented a single isolate from a particular patient and none was associated with a recognised outbreak. The 35 Argentinian strains were submitted to the National Reference Laboratory by different hospitals. The 20 Australian and 18 New Zealand strains were submitted by various diagnostic laboratories in both countries to the Department of Microbiology and Immunology, University of Melbourne, for confirmation of their identity and further characterisation. In keeping with the guidelines of our human ethics committees, all strains were coded to protect patient confidentiality. The distribution of strains isolated from patients in Argentina, Australia, and New Zealand by clinical presentation is shown in Table 1.

\section{Phenotypic and genotypic characteristics of isolates}

All strains were confirmed to be E. coli O157 by biochemical tests [22], and serotyping using somatic and flagellar antisera obtained from the Instituto Nacional de Producción de Biológicos - ANLIS "Dr. Carlos G. Malbrán" [23]. The presence of $s t x_{1}, s t x_{2}$ and $r f b_{\mathrm{O} 157}$ was determined by means of a multiplex PCR [24]. The reference E. coli strains, EDL933 O157:H7 (stx $\left.1, s t x_{2}\right)$, and non-pathogenic E. coli ATCC 25922 were used as positive and negative 
controls, respectively. Enterohaemolysin production was detected on sheep blood agar plates [25]. To determine Stx production, bacterial supernatant and periplasmic cell extracts were used in cytotoxicity assays on Vero cells [26] using Stx1- and Stx2- specific monoclonal antibodies (MAb 13C4 and BC5BB12, respectively) kindly provided by Dr. N. A. Strockbine, Centers for Disease Control and Prevention, Atlanta, GA, USA. Additional virulence markers were characterised by PCR. The intimin (eae) and $e h x A$ genes were detected by PCR $[4,27]$. The presence of the $\mathrm{fli}_{\mathrm{H} 7}$ gene was tested as described by Gannon et al. [28].

\section{Subtyping of isolates}

Genotyping of $s t x_{2}$ variants was done by RFLP analysis of the B-subunit-encoding DNA fragments obtained by PCR [29] and extended to include primers and restriction enzymes as described by Pierard et al. [30]. The reference E. coli strains 92-3580 O157:H7 ( stx $\left._{2 \text { vh-a }}\right)$ and 93-016 O113:H21 ( $\left.\mathrm{stx}_{2 \text { vh-b }}\right)$ were kindly provided by Dr. D. Woodward, of the National Microbiology Laboratory, Public Health Agency ofCanada, Winnipeg, Manitoba, Canada. $s t x_{1}$ variants were identified by RFLP and PCR [31]. Phage typing was performed by the method originally described by Ahmed et al. [32] and extended by Khakhria et al. [17]. The E. coli O157 typing phages used were kindly provided by R. Ahmed, of the National Microbiology Laboratory, Winnipeg, Manitoba, Canada. Macrorestriction fragment analysis by PFGE was performed using the 24-h PulseNet standardised PFGE protocol for E. coli O157:H7 [33] with minor modifications. Restriction digestion of DNA embedded in plugs was performed with $30 \mathrm{U}$ of $\mathrm{Xba \textrm {I }}$ or B $\ln \mathrm{I}$ (Promega Corp., Madison, WI, USA) at $37^{\circ} \mathrm{C}$ overnight. The PulseNet size standard strain used was Salmonella Braenderup H9812 (kindly provided by the Centers for Disease Control, Atlanta, GA, USA). DNA fragments were resolved in 1\% pulsed-field SeaKem Gold agarose (FMC Bioproducts, Rockland, ME, USA) in 0.5× TBE buffer at $14^{\circ} \mathrm{C}$. PFGE was performed using a CHEF DR-III system (Bio-Rad Laboratories, Hercules, CA, USA), using a linear pulse ramp of 2.2-54.2 sec with a run length of $18 \mathrm{~h}$ and a constant voltage of $200 \mathrm{~V}$. Images of gels were obtained using a Gel Doc 2000 (Bio-Rad Laboratories). Analysis of TIFF images was performed using the BioNumerics software package (Applied Maths, Kortrijk, Belgium) using the Dice coefficient and UPGMA to generate dendrograms with $1.5 \%$ tolerance values. The clonal relationship analysis was confirmed visually.

\section{Statistical analysis}

Statistical analysis of data was performed using InStat version 3.05 (GraphPad Software Inc., San Diego, CA, USA).

\section{Authors' contributions}

GAL and EME performed the detection of virulence genes by PCR, the typing of the stx genes by RFLP-PCR and XbaI-
PFGE. EM was the responsible for the phage typing and the cytotoxicity assays on Vero cells. GAL and IC carried out the analysis of the PFGE results. MR designed the study and, together with GAL, drafted the manuscript. KA, ST and RRB were involved in the initial isolation and characterisation of the Australian and New Zealand strains. RRB prepared the final version of the manuscript together with GAL and MR. All authors read, commented on and approved the final manuscript.

\section{Acknowledgements}

This study was supported by grant from Fundación Alberto J. Roemmers Argentina and the Australian National Health and Medical Research Council. ST was the recipient of a JN Peters Bequest Fellowship from The University of Melbourne.

\section{References}

I. Pradel N, Boukhors K, Bertin Y, Forestier C, Martin C, Livrelli V: Heterogeneity of Shiga toxin-producing Escherichia coli strains isolated from haemolytic-uremic patients, cattle and food samples in Central France. J Clin Microbiol 200I, 67(6):2460-2468.

2. Beutin L, Krause G, Zimmermman S, Kaulfuss S, Gleier K: Characterization of Shiga toxin-producing Escherichia coli strains isolated from human patients in Germany over a 3-year period. J Clin Microbiol 2004, 42: 1099 -I I 08.

3. McDaniel TK, Jarvis KG, Donnenberg MS, Kaper JB: A genetic locus for enterocyte effacement conserved among diverse enterobacterial pathogens. Proc Natl Acad Sci USA 1995, 92:1664-1668.

4. Schmidt H, Beutin L, Karch H: Molecular analysis of the plasmidencoded hemolysin of Escherichia coli O157:H7 strain EDL 933. Infect Immun 1995, 63:1055-106I.

5. Rivas M, Miliwebsky E, Chinen I, Deza N, Leotta GA: Epidemiología del síndrome urémico hemolítico en Argentina. Diagnóstico del agente etiológico, reservorios y vías de transmisión. Medicina (Buenos Aires) 2006, 66(Suppl III):27-32.

6. Mead PS, Griffin PM: Escherichia coli O157:H7. Lancet 1998, 352: $1207-12 \mid 2$.

7. Rivas M, Miliwebsky E, Chinen I, Roldán CD, Balbi L, García B, Fiorilli G, Sosa-Estani S, Kincaid J, Rangel J, Griffin PM, the Case-Control Study Group: Characterization and epidemiologic subtyping of Shiga toxin-producing Escherichia coli strains isolated from hemolytic uremic syndrome and diarrhea cases in Argentina. Foodborne Path Dis 2006, 3:88-96.

8. Elliott EJ, Lynn R, Schmid F, Proulx F, Wong W, Sockett P, Ssilva JE, Adek R, on behalf of members of the Australian, British, Canadian, New Zealand, Swiss and Portuguese Paediatric Surveillance Units' HUS study groups: Haemolytic uraemic syndrome - an international perspective. Portuguese Paediatric Surveillance Unit Bulletin 2004, 5( I): I 4. [ISSN: I645-0558].

9. Elliott Ej, Robins-Browne RM, O'Loughlin EV, Henning P, Hogg GG, Knight J, Powell H, Redmond D, Bennett-Wood V, Contributors to the Australian Paediatric Surveillance Unit: Nationwide surveillance of hemolytic uremic syndrome in Australia: a comparison of endemic cases with those in a single epidemic. Arch Dis Child 200I, 85: I25-I3I.

10. Griffin PM: Escherichia coli OI57:H7 and other Enterohemorrhagic Escherichia coli. In Infections of the gastrointestinal tract Edited by: Blaser MJ, Smith PD, Ravdin JI, Greenberg HB, Guerrant RL. New York: Raven Press; 1995:739-761.

II. Izumiya H, Terajima J, Wada A, Inagaki S, Itoh K, Tamura K, Watanabe $\mathrm{H}$ : Molecular typing of enterohemorrhagic Escherichia coli O 157:H7 isolates in Japan by using pulsed-field gel electrophoresis. J Clin Microbiol I997, 35:1675-1680.

12. Ríos M, Prado V, Trucksis M, Arellano C, Borie C, Alexandre M, Fica A, Levine MM: Clonal diversity of Chilean isolates of enterohemorrhagic Escherichia coli from patients with hemolytic-uremic syndrome, asymptomatic subjects, animal reservoirs, and food products. J Clin Microbiol 1999, 37:778-78I.

13. Van der Kar NCAJ, Roelofs HGR, Muytjens HL, Tolboom J], Roth B, Proesmans W, Reitsma-Bierens WC, Wolff ED, Karmali MA, Chart 
$\mathrm{H}$, Monnens LA: Verocytotoxin-producing Escherichia coli infection in hemolytic uremic syndrome in part of Western Europe. Eur J Pediatr 1996, 155:592-595.

14. Pradel N, Livrelli V, Champs C, Palcoux JB, Reynaud A, Scheutz F, Sirot J, Joly B, Forestier C: Prevalence and characterization of Shiga toxin-producing Escherichia coli isolated from cattle, food, and children during a one-year prospective study in France. J Clin Microbiol 2000, 38:1023-103I.

15. Nishikawa Y, Hase A, Ogasawa J, Cheasty T, Willshaw GA, Smith HR Tatsumi Y, Yasukawa A: Phage typing and DNA-based comparison of strains of enterohemorrhagic Escherichia coli 0157 from apparently sporadic infections in Osaka City, Japan, 1996. J Infect Dis 200I, 54(4): I40-I43.

16. Werber D, Fruth A, Buchholz U, Prager R, Kramer MH, Ammon A, Tschape H: Strong association between Shiga toxin-producing Escherichia coli 0157 and virulence genes stx 2 and eae as possible explanation for predominance of serogroup 0157 in patients with haemolytic uraemic syndrome. Eur J Clin Microbiol Infect Dis 2003, 22:726-730.

17. Khakhria R, Duch D, Lior H: Extended phage-typing scheme for Escherichia coli O 157:H7. Epidemiol Infect 1990, 105:5 I 1-520.

18. Mora A, Blanco M, Blanco JE, Alonso MP, Dahbi G, Thompson-Carter F, Usera MA, Bartolomé R, Prats G, Blanco J: Phage types and genotypes of human and animal predominating phage types (PT2 and PT8). J Clin Microbiol 2004, 42:4007-40I5.

19. Mora A, Blanco M, Blanco JE, Alonso MP, Dahbi G, López C, Justel P, Alonso MP, Echeita A, Bernárdez MI, González EA, Blanco J: Serotypes, virulence genes and intimin types of Shiga toxin (Verotoxin)-producing Escherichia coli isolates from minced beef in Lugo (Spain) from 1995 through 2003. BMC Microbiol 2007, 7: 13 .

20. Gerner-Smidt P, Hise K, Kincaid J, Hunter S, Rolando S, Hyytia-Trees E, Ribot EM, Swaminathan B, Pulsenet Taskforce: PulseNet USA: a five-year update. Foodborne Pathog Dis 2006, 3:9-19.

21. Laine ES, Scheftel JM, Boxrud DJ, Vought KJ, Danila RN, Elfering KM, Smith KE: Outbreak of Escherichia coli O157:H7 infections associated with non intact blade-tenderized frozen steaks sold by door-to-door vendors. J Food Protect 2005, 68: I I 98-I 202.

22. Ewing WH: Identification of Enterobacteriaceae 4th edition. New York: Elsevier; 1986.

23. Ørskov F, Ørskov I: Serotyping of Escherichia coli. In Methods in Microbiology Volume 14. Edited by: Bergan T. London: Academic Press; 1984:43-II2.

24. Leotta GA, Chinen I, Epszteyn S, Miliwebsky E, Melamed IC, Motter M, Ferrer M, Marey E, Rivas M: Validation of a multiplex PCR for detection of Shiga toxin-producing Escherichia coli. Rev Arg Microbiol 2005, 37: I-I0.

25. Beutin L, Montenegro MA, Ørskov I, Prada J, Zimmermann S, Stephan $\mathrm{R}$ : Close association of Verotoxin (Shiga-like toxin) production with enterohemolysin production in strains of Escherichia coli. J Clin Microbiol 1989, 27:2559-2564.

26. Karmali MA, Petric M, Lim C, Cheung R, Arbus GS: Sensitive method for detecting low numbers of Verotoxin-producing Escherichia coli in mixed cultures by use of colony sweeps and polymyxin extraction of Verotoxin. J Clin Microbiol 1985, 22:6|4-619.

27. Karch H, Böhm H, Schmidt H, Gunzer F, Aleksic S, Heesemann J: Clonal structure and pathogenicity of Shiga-like toxin producing, sorbitol-fermenting Escherichia coli OI57:H-. J Clin Microbiol 1993, 31: 1200-I 205.

28. Gannon VP, D'Souza S, Graham T, King RK, Rahn K, Read S: Use of the flagellar $\mathrm{H} 7$ gene as a target in multiplex PCR assays and improved specificity in identification of enterohemorrhagic Escherichia coli strains. J Clin Microbiol 1997, 35:656-662.

29. Tyler SD, Johnson WM, Lior H, Wang G, Rozee KR: Identification of Verotoxin type 2 variant B subunit genes in Escherichia coli by the polymerase chain reaction and restriction fragment length polymorphism analysis. J Clin Microbiol 1991, 29:1339-1343.

30. Pierard D, Muyldermans G, Moriau L, Stevens D, Lauwers S: Identification of new verocytotoxin type 2 variant $B$-subunit genes in human and animal Escherichia coli isolates. J Clin Microbiol 1998, 36:3317-3322.

31. Zhang W, Bielaszewska M, Thorsten $\mathrm{K}, \mathrm{Karch} \mathrm{H}$ : Identification, characterization, and distribution of a Shiga toxin I gene variant (stx|c) in Escherichia coli strains isolated from humans. J Clin Microbiol 2002, 40: I44I-I 446.

32. Ahmed R, Bopp C, Borczyk A, Kasatiya S: Phage-typing scheme for Escherichia coli serotype O157:H7. J Infect Dis 1987, 155:806-809.

33. Centers for Disease Control and Prevention: Standardized Molecular Subtyping of Foodborne Bacterial Pathogens by Pulsed-Field Gel Electrophoresis. The National Molecular Subtyping Network for Foodborne Disease Surveillance. Atlanta 2004.
Publish with Biomed Central and every scientist can read your work free of charge

"BioMed Central will be the most significant development for disseminating the results of biomedical research in our lifetime. "

Sir Paul Nurse, Cancer Research UK

Your research papers will be:

- available free of charge to the entire biomedical community

- peer reviewed and published immediately upon acceptance

- cited in PubMed and archived on PubMed Central

- yours - you keep the copyright 